\title{
Cash Flow Statement as an Evidence for Financial Distress
}

\author{
Naz Sayari ${ }^{1{ }^{* *}, \text { F.N. Can Simga Mugan }}{ }^{2}$ \\ ${ }^{1}$ Department of Business Administration, Middle East Technical University, Ankara, 06800, Turkey \\ ${ }^{2}$ Department of Business Administration, Izmir University of Economics, İzmir, 35330, Turkey \\ *Corresponding Author: nazsayari@yahoo.com
}

Copyright $@ 2014$ Horizon Research Publishing All rights reserved.

\begin{abstract}
In this study, the effect of cash flow components on financial distress score is examined for 124 companies selected from Istanbul Stock Exchange (ISE). It is further analyzed whether cash flow components have an explanatory effect on bankruptcy risk and financial health of companies. Four separate models are constituted and Linear Regression Model is used to evaluate company age, company size, cash flow from operations (CFO), cash flow from investing (CFI) and cash flow from financing (CFF) activities as a function of financial distress score of companies. The results show that there is a negative relationship between CFO, company size and financial distress score of companies. On the contrary, CFF is observed to be positively related with the financial distress score. Meanwhile, it is further observed that the standardized coefficient of CFI is statistically insignificant and hence it does not provide any evidence for the financial weakness or bankruptcy risk of companies.
\end{abstract}

Keywords Cash Flow Statement, Cash Flow from Operations, Cash Flow from Investing, Cash Flow from Financing, Financial Distress Score, Bankruptcy Risk, Financial Health

\section{Introduction}

The aim of the article is to examine whether components of cash flow statements; cash flows from operations (CFO), cash flows from investing activities (CFI) and cash flows from financing activities (CFF), contain relevant information in explaining deterioration or financial health of companies. We also investigate whether cash flow patterns have any significant effect on financial distress score of companies. Financial distress can be defined as a late stage of corporate decline or as an early warning model for financial health, which is used in predicting bankruptcy or liquidation problem of firms. Notwithstanding, the objective of this paper is to explain whether cash flow pattern of companies have any explanatory power in predicting the bankruptcy risk of related firms. To our knowledge, there are few studies that analyze the relation between financial distress and CFO component of cash flows, but no study includes CFI and CFF in bankruptcy prediction studies. In this respect, we contribute to existing literature by evaluating information content of each cash flow component in explaining financial weakness or healthiness of companies. The study further illustrates whether company age and company size has any significant impact on determination of financial distress score among companies.

The paper also contributes to the prior literature by providing the financial distress score of firms selected from manufacturing and service sectors that are traded in the stock market of Turkey. In this respect, the study extends the subject of value relevance of cash flow statements as an evidence for financial distress, by illustrating detailed financial information about firms in a developing country.

\section{Literature Review}

In the prior literature cash flow analysis are examined mainly for two reasons. First reason is to explore whether cash flow components carry information about financial health of a company and to use that information to derive firms' life cycle stages. Second reason is to analyze the value relevance of operating, investing and financing cash flows versus the value relevance of earnings and accruals.

To start with, Gentry et al.[1] evaluates the contributions of cash flow components to identify financial health of a company. The researchers state that, if a company's cash flows from operations (CFO) increase, the financial and credit health of the firm would also increase as the firm would less likely to need borrowing and cash interest expense. Contrarily, if a company's CFO declines, it would be more likely to use interest bearing debt to finance its plans and investments. They employ Helfert approach to analyze cash flow components and observe that, firms with high CFO and cash outflow from investing activities would also likely to have low credit risk. The results also show that, CFO has more information content than investing and financing cash 
flows in explaining financial success or failure of a firm.

Dickinson[2] examines the cash flow patterns as a proxy for firm life cycle that is derived from accounting information. The researcher indicates that cash flow patterns supply a rigid and robust indicator of firm life cycle stage and allows researchers to evaluate a firm's current performance as well as predicts its future performance according to firm's current life cycle stage. In this respect, Dickinson divides life cycle of firms into 5 phases namely introduction, growth, maturity, shake out and decline. The classification of life cycle stages are constituted by using firm's operating, investing and financing cash flows in which firm life cycle is completely separated from firm's age. The researcher uses life cycle proxy in order to assess the economic, market and accounting behavior of firms within each life cycle stage and develops a method for identifying firm life cycle using the combination of cash flow patterns. First, Dickinson makes an ex ante assumption considering a uniform distribution of life cycle stages across firms and uses the sign of the net operating, investing and financing cash flows and determines eight possible cash flow patterns combinations. The study uses NYSE, AMEX and NASDAQ firms in determining the sample for the 1989-2005 period. Dickinson demonstrates several variables such as profitability, stock returns, financial leverage, risk, tax rates, dividend payments, age and size which have a non linear relationship with firm life cycle. The researcher conducts probit analysis to explain how these variables are related to life cycle and uses life cycle proxy to assess profitability in the financial statement analysis. Dickenson conducts probit model to evaluate life cycle stage with respect to thirteen variables covering return ratios, earnings per share, sales and dividend payments. The researcher further determines a base model, where changes in return on net operating assets are regressed as a function of current profitability and lagged profitability. In the analysis, Chow test is conducted on the full sample versus life cycle stage subsamples in order to measure whether the coefficients in the separate subsamples are equal across life cycle stage. As a conclusion it is found that, the structural shift among life cycle stages is significant. It is further observed that, incorporating information about firm life cycle improves the explanatory power of future profitability. Specifically, current and past profitability, growth in net operating assets and the changes in asset turnover have significant effect in explaining future profitability. Consequently the results show that, cash flow patterns are robust indicators of firm life cycle stages.

Gort and Klepper[3] defines the life cycle stages as introductory stage-where an innovation is first produced, growth stage-where the number of producers increases dramatically, maturity stage- where the number of producers reaches a maximum, shake out stage-where the number of producers begins to decline and decline stage in which there is nearly zero net entry. Inspired by Gort and Klepper's definition of life cycles, Dickinson demonstrates that in the introduction stage, net operating cash flows are negative since firms are initially learning their cost structures and operating environments. Investing cash flows are also negative because of managerial optimism that investment opportunities are growing. In this stage financing cash flows are expected to be positive since they borrow from creditors or issue stock. In the growth stage, operating cash flows would be positive since firm's main purpose is to maximize their profit margins. Investing cash flows as well as financing cash flows are also expected to be positive since firms continue to invest and finance their investment in order to grow more. In mature stage, operating cash flows are still positive although profitability decreases. Meanwhile, financing and investing cash flows are negative since the firm invests to maintain capital rather than to grow and to service its debt rather than to acquire new financing. In the shakeout stage, cash flow expectations are ambiguous and hence cash flows from operating, financing and investing can be either positive or negative. Finally, in the decline stage, operating cash flows are expected to be negative and investing cash flows are expected to be positive since firms are aimed to liquidate their assets and finance their operations as well as service their debt. However, firms in this stage may also seek for additional funds to downturn their position so that the sign of financing cash flows is indeterminable.

In 1978 FASB declared that financial reporting should focus on earnings rather than cash flows. However, because of increase in business failures and high interest rates, a debate started regarding the usefulness of accrual accounting numbers versus cash flow data. In this respect, Bowen et al.[4] examine whether cash flow data has information content in explaining stock prices and whether accruals has incremental value relevance above cash flow numbers. They define earnings and working capital from operations (WCFO) as accrual based measures and cash flow from operations as a cash flow measure. The study uses market model to examine expected return in the event period that covers the release date of financial statements to the public. They also use regression analysis to examine the incremental information content of independent variables where unexpected return is regressed on unexpected WCFO, unexpected earnings and unexpected CFO. The regression results show a significant relation between earnings and unexpected returns, while no evidence is observed for the incremental explanatory power of WCFO above information content of earnings. On the contrary, the outcomes reveal that unexpected CFO contains incremental value relevant information above unexpected earnings.

To examine the information content of accruals and cash flows Bernard and Stober[5] decompose earnings as CFO, current accruals, WCFO and noncurrent accruals, where current accruals contain increases in inventories and receivables, decreases in payables, while noncurrent accruals contain depreciation and deferred income taxes. They replicate Wilson's[6] study and employ regression analysis, where abnormal return is regressed on unexpected CFO, unexpected current accruals and unexpected noncurrent accruals. They further conduct an event study to estimate 
expected CFO and WCFO after the earnings announcement date. Contrary to Wilson's findings stating a larger price reaction to cash flows than accruals for a given amount of earnings, they observed no significant reaction either for cash flows or for accruals data. Regression results also do not provide any significant evidence regarding value relevance of cash flow or accruals data in explaining stock returns. They conclude that, Wilson's findings cannot be generalized since the reaction of prices to the release of cash flow and accruals data is highly contextual to be modeled or there is information leakage regarding financial statements before the announcement date so that the information contained in these statements generates no surprise in the public.

Black[7] investigates the value relevance of earnings, operating, financing and investing cash flows in four different life cycle stages namely start up, growth, maturity and decline stage. He demonstrates the differences between life cycle stages by using the firm value definition of Myers[8], who divides firm value into two components: assets in place and growth opportunities. According to Myers, in early life cycle stages, growth opportunities are a larger component of firm value, whereas in later stages assets in place become the largest component. As a result Black observes that, at least one of the components in cash flow statements (operating, financing and investing) is useful in explaining stock returns in each firm life cycle stage. The researcher further demonstrates that, the value relevance of a particular cash flow component depends on the life cycle stage of the firm.

Black states that, in the start up and decline life cycle stages operating cash flow is expected to be negative, since the companies would likely to face financial difficulties during these stages in funding their obligations. On the contrary, cash flow from operations is expected to be positive in the growth and mature stages, since the companies would likely to generate cash in these periods. Meanwhile cash flow from financing is expected to be positive in the early life cycle stages and turn out to be negative in the later stages. In addition, cash flow from investing is expected to be negative in the early stages while positive in the later stages. Black also includes earnings as an additional indicator other than cash flow components and reveals that, in the start up and decline life cycle stages earnings are expected to be negative, while in the growth and mature phases earnings would be positive. The researcher classifies life cycle stages considering the sales growth, capital expenditure, dividend payout and age of firms. For instance, a firm is classified in the growth stage if it is in the highest quintile of the combined score for sales growth and capital expenditure and in the lowest quintile of the combined score of dividend payout and firm age. On the contrary, a firm is classified in the mature stage if it is in the middle quintile of the combined score of sales growth and capital expenditure while in the highest quintile on dividend payout and in the middle quintile on firm age. As a conclusion, Black finds that, start up stage shows limited usefulness of earnings and cash flow accounting information.
In addition operating and financing cash flows have the expected sign, negative and positive respectively. In the growth stage, although cash flow measures are value relevant, earnings are not. In the mature stage, earnings, operating and financing cash flows are value relevant and earnings and operating cash flow have the expected sign; positive for both indicators. Finally, in the decline stage all cash flow measures have the expected signs, while the same result cannot be achieved for earnings at this stage.

Regarding Black's findings that information of earnings do not possess useful information while cash flow information is still value relevant in distressed firms, Joseph and Lipka[9] reexamine whether informativeness of earnings really declined in case of financial distress. They employed the following model to investigate alleged deterioration in information content of earnings and value relevance of CFO: Firm value $=f($ expected performance, adaptation value of assets)

The results show that information content of earnings decline because of operating difficulties. However value relevance of cash flow also declines over the same time period, indicating neither earnings nor cash flows provide useful information in explaining stock prices in the financially distressed periods.

Livnat and Zarowin[10] examine whether components of operating, financing and investing cash flows are differentially associated with annual security returns and find similar results with Black[7]. Financing cash flow is incrementally value relevant in the growth and maturity stages. They further found that disaggregating net income into cash flow from operations and accruals does not contribute to the security returns when it is compared to the contribution of the net income alone. Moreover, they do not find any evidence for differential association between the components of cash flows from investing and their contribution to annual security returns. Dechow[11] also examines the circumstances under which accruals are predicted to enhance earnings ability to assess firm performance and concludes that, cash flows suffer more severely from timing and matching problems that reduce their ability to reflect firm performance.

Overall, there are mixed evidence regarding the incremental value relevance of cash flows over accounting earnings in explaining stock price reaction. However, many studies reveal that cash flow components contain relevant information in identifying financial health or deterioration of companies. In the light of prior literature findings, our aim is to show whether cash flow components have information content in determining financial distress score of firms and whether cash flow patterns have any significant effect in identifying financial weakness or healthiness of companies.

\section{Methodology and Design}

In the first phase of this study, cash flow statements of 151 firms from manufacturing and service sectors are selected 
from Istanbul Stock Exchange (ISE) and the sign of each cash flow component are investigated. The data are collected for the period $2005-2009$. In the second phase, 27 firms are eliminated from the selected sample since it is observed from the yearend cash flow statements that some of the cash flow components of these firms were static. It is further observed that, these firms possess extreme values of financial distress scores so that they are determined as outliers and dropped from the model. In the third phase, linear regression is used to model the effect of company size, company age and cash flow pattern on financial distress score for each sector. For the first model, the estimated regression model is as follows:

$$
\mathrm{Y}=\beta_{0}+\beta_{1} \mathrm{X}_{1}+\beta_{2} \mathrm{X}_{2}+\beta_{3} \mathrm{X}_{3}+\epsilon
$$

where;

$\mathrm{Y}=$ Financial Distress Score

$\mathrm{X}_{1}=$ Company Age

$\mathrm{X}_{2}=$ Company Size

$\mathrm{X}_{3}=$ Cash Flow Pattern $\left(\mathrm{X}_{3}=0,1,2 \ldots \ldots 8\right)$

As mentioned before financial distress is determined as a late stage of corporate decline or as an early warning model for financial health of firms and it is used in predicting bankruptcy or liquidation problem of related companies. Financial distress score (FD) is calculated using Zmijewski's model[12] which is assessed as follows:

$$
F D=-4,803-3,6\left(\frac{N I}{T A}\right)+5,4\left(\frac{T L}{T A}\right)-0,1\left(\frac{C A}{C L}\right)
$$

where NI stands for net income, TA stands for total assets, TL stands for total liabilities, CA stands for current assets and CL stands for current liabilities.

It should be noticed that negative financial distress score indicates a relatively stronger financial health, whereas positive financial distress score refers to a relatively weaker financial health. In other words, as the financial distress score increases, the probability of bankruptcy risk also increases. Company size is the logarithmic function of total assets that are obtained from the yearend financial statements and company age is determined by subtracting year of incorporation from 2009. In the evaluation of cash flow patterns, 8 patterns are determined which are constituted according to the sign of each cash flow component. The cash flow patterns are illustrated in Table 1:

Table 1. Cash Flow Patterns

\begin{tabular}{ccccccccc}
\hline Pattern & 1 & 2 & 3 & 4 & 5 & 6 & 7 & 8 \\
\hline $\mathrm{CFO}$ & + & + & + & + & - & - & - & - \\
$\mathrm{CFI}$ & + & + & - & - & - & - & + & + \\
$\mathrm{CFF}$ & + & - & + & - & + & - & + & - \\
\hline
\end{tabular}

For the first pattern, cash inflows are said to be unsustainable and such a pattern can only be maintained temporarily. Second pattern refers to a company that generates cash, while it also sells assets to cover debt or purchase treasury stock. Third pattern demonstrates cash generating company but also requiring additional funding through debt or stock issuance. Fourth pattern, corresponding to a strong cash flow pattern, generates enough cash from operations to finance capital investment and repay debt or purchase own shares. Fifth pattern refers to a company that could not generate enough cash to finance operations or capital expansion. As a result new debt or stock is issued to cover current and long term obligations. Sixth one can be regarded as an unusual pattern which is possible only with maintaining cash reserves. Similarly seventh pattern is also an unusual one, which can be seen in companies that could not generate sufficient cash from operations and at the same time finances its operations by selling assets while obtaining loans or issuing stock. Finally, eighth pattern demonstrates a company where long term assets are sold to finance operations and pay off debt.

Considering the first model, it is predicted for the companies that as the company age and company size grow, financial distress score of companies would likely to decrease since financial strength of mature companies are expected to be higher and bankruptcy risk would likely to be lower than growing or early stage companies. Additionally, financial distress score is expected to be positively related to cash flow pattern since higher cash flow patterns lead to weaker financial health and companies that have higher cash flow patterns are exposed to bankruptcy risk more than companies that have lower cash flow patterns. In this respect the hypothesis for the first model is considered as follows:

$$
\mathrm{H}_{01}: \beta_{1}=\beta_{2}=\beta_{3}=0
$$

The frequencies of cash flow patterns illustrated in Table 2 reveals that 217 of the observations within the years 2005-2009 correspond to pattern four referring positive CFO, negative CFI and CFF. 154 of the observations correspond to pattern three showing negative CFI, positive CFO and CFF, and 125 of the observations correspond to pattern five showing positive CFF, negative CFO and CFI. The frequency results indicate that, majority of the companies show a strong cash flow pattern and finance their capital investment through cash flow from operations and are able to repay their debt or purchase their own shares. Meanwhile, considering rest of the companies which possess third and fifth cash flow patterns, it can be stated that the companies that are included in the third pattern can be regarded as cash generating companies however they further need to generate cash through debt or stock issuance.

Table 2. Frequency of Cash Flow Patterns

\begin{tabular}{cccc}
\hline & Frequency & Percent \\
\hline Pattern & $1(+,+,+)$ & 6 & 1 \\
& $2(+,+,-)$ & 58 & 9,4 \\
$3(+,-,+)$ & 154 & 24,8 \\
$4(+,-,-)$ & 217 & 33,4 \\
$5(-,-,+)$ & 125 & 20,2 \\
$6(-,-,-)$ & 21 & 3,4 \\
& $7(-,+,+)$ & 26 & 4,2 \\
& $8(-,+,-)$ & 13 & 2,1 \\
& Total & 620 & 100 \\
\hline
\end{tabular}


On the contrary, other companies which are included in the fifth pattern could not generate enough cash to finance operations or capital expansion.

To assess whether cash flow patterns at year (t-1) have significant effect on financial distress score at year $t$, the lag of cash flow pattern variable is included in the regression model as follows:

$$
Y_{t}=\beta_{0}+\beta_{1} X_{1 t}+\beta_{2} X_{2 t}+\beta_{3} X_{3(t-1)}
$$

where $\mathrm{X}_{3(\mathrm{t}-1)}$ refers to lagged cash flow pattern at year t-1 and $\mathrm{t}=(2006,2007,2008,2009)$

It is expected that an increase in the cash flow pattern for the previous year would likely to increase financial distress score of companies. Related hypothesis for the model is as follows:

$$
\mathrm{H}_{02}: \beta_{1}=\beta_{2}=\beta_{3}=0
$$

In order to observe the individual effects of each cash flow component on the financial distress score of companies, third regression model is formed. In this model, rather than cash flow patterns, dummy variables are used for cash flows from operations, cash flows from financing and cash flows from investing separately. Company size and company age are also included in the model as follows:

$$
Y=\beta_{0}+\beta_{1} X_{1}+\beta_{2} X_{2}+\beta_{4} X_{4}+\beta_{5} X_{5}+\beta_{6} X_{6}
$$

where;

$\mathrm{Y}=$ Financial Distress Score

$\mathrm{X}_{1}=$ Company Age

$\mathrm{X}_{2}=$ Company Size

$\mathrm{X}_{4}=$ Cash Flows from Operations; if $\mathrm{CFO}>0 ; \mathrm{X}_{4}=1$; otherwise - 0 -

$\mathrm{X}_{5}=$ Cash Flows from Investing; if CFI $>0 ; \mathrm{X}_{5}=1$; otherwise $-0-$

$\mathrm{X}_{6}=$ Cash Flows from Financing; if $\mathrm{CFF}>0 ; \mathrm{X}_{6}=1$; otherwise - 0 -

In this model, it is predicted that increase in CFO would have a decreasing effect in financial distress score. It is because, $\mathrm{CFO}$ is the cash that companies generate through operations and it is defined as revenues less operating expenses. Similarly, it is expected that increase in CFI would have a decreasing effect in financial distress score since CFI increases as cash position resulting from any gains from investments in the financial markets increases, thereby improving the financial performance of the company. Meanwhile, considering the third component of cash flow statement, CFF is predicted to be positively related to financial distress score. CFF increases as the companies rely more on issuing or selling stock, which would result in a degrading effect in the financial health of firms unless they are categorized as growing companies. Related hypothesis for the model is as follows:

$$
\mathrm{H}_{03}: \beta_{1}=\beta_{2}=\beta_{4}=\beta_{5}=\beta_{6}=0
$$

Finally, to disregard the size effect from financial distress score and to normalize the cash flow components, we generate Model 4 which excludes company size variable and normalizes $\mathrm{CFO}, \mathrm{CFI}$ and $\mathrm{CFF}$ variables by dividing the amounts to total asset values:

$$
\mathrm{Y}=\beta_{0}+\beta_{1} \mathrm{X}_{1}+\beta_{4} \mathrm{X}_{4}+\beta_{5} \mathrm{X}_{5}+\beta_{6} \mathrm{X}_{6}+\epsilon
$$

Where;

$\mathrm{X}_{4}=$ Cash Flows from Operations/Total Assets

$\mathrm{X}_{5}=$ Cash Flows from Investing/Total Assets

$\mathrm{X}_{6}=$ Cash Flows from Financing/Total Assets

The hypothesis relating to the fourth model is as follows:

$$
\mathrm{H}_{04}: \beta_{1}=\beta_{4}=\beta_{5}=\beta_{6}=0
$$

To check the robustness of the data for the first equation, Pearson Correlation Matrices as well as Coefficient Correlations are derived which indicate that there is no significant correlation between financial distress score as a dependent variable and company size, company age and cash flow patterns as independent variables. For the third equation covering $\mathrm{CFO}, \mathrm{CFI}$ and $\mathrm{CFF}$ as separate independent variables there is no significant correlation between dependent and independent variables either. Furthermore, collinearity statistics are also conducted for each of the three models. As a consequence, the VIF as well as Tolerance measures are found at conceivable levels. On the contrary, in the fourth model, it is observed in the Pearson Correlation Test that the correlation between CFO and CFF is $-0,614$. However according to the Collinearity Diagnostic Test it can be concluded that, the correlation between CFO and CFF is conceivable since condition index values are at immaterial levels.

\section{Results}

Descriptive statistics of Model 1 is illustrated in Table 2. The regression results of the first model including company size, company age and cash flow patterns as independent variables indicate that, cash flow pattern and company size have a significant effect on financial distress score of companies. The $\mathrm{R}^{2}$ of the model is 0,074 which indicate that $7,4 \%$ of the variation in financial distress score can be explained by the linear relationship between the company size, cash flow pattern, company age and financial distress score (See Table 6 in the Appendix).

Table 3. Descriptive Statistics of Model 1

\begin{tabular}{cccc}
\hline & Mean & Std.Deviation & $\mathrm{N}$ \\
\hline YFD & $-2,2860$ & 2,8611 & 755 \\
X1age & 33,5457 & 12,5648 & 755 \\
X2size & 19,0411 & 1,6163 & 755 \\
X3pattern & 4,1536 & 1,4892 & 755 \\
\hline
\end{tabular}

The frequency of financial distress score ranges between $-6,57$ and 4,41 which shows that, the healthiest company in financial matters shall obtain the lowest financial distress score of $-6,67$ and the weakest company would get the highest financial distress score of 4,41. ANOVA test is conducted at the 0,01 level of significance (See Table 7 in the 
Appendix). Consequently, $\mathrm{H}_{01}$ is rejected and concluded that there is a statistically significant relation between financial distress score and cash flow patterns as well as company size. The linear regression analysis show that, an increase in the cash flow pattern from pattern 1 through pattern 8 would result in an increase in the financial distress score meaning that firms having higher patterns in the cash flow analysis would likely to have weaker financial health and exposed to higher bankruptcy risk. The standardized coefficient of company size $\left(\mathrm{X}_{2}\right)$ and cash flow pattern $\left(\mathrm{X}_{3}\right)$ are $-0,166$ and 0,142 respectively (See Table 8 in the Appendix). The results indicate that, one unit increase in the company size would likely to decrease financial distress by 0,166 units. Similarly one unit increase in the cash flow pattern would likely to increase financial distress score by 0,142 units. Meanwhile, from the coefficient test it is observed that $\mathrm{p}$-value of $\mathrm{X}_{1}$ is above 0,01 significance level of significance which indicate that the relation between company age and financial distress score is not statistically significant.

Second model, including lagged cash flow patterns, shows that, previous years' cash flow patterns do not have any significant effect on current years' financial distress scores for the sample period (See Table 9, Table 10, Table 11 and Table 12 in the Appendix). Extension of time period and panel data analysis are needed to obtained significant results for the lagged model.

Descriptive statistics of Model 3 is illustrated in Table 4.

Table 4. Descriptive Statistics of Model 3

\begin{tabular}{cccc}
\hline & Mean & Std.Deviation & $\mathrm{N}$ \\
\hline YFD & $-2,2860$ & 2,8611 & 755 \\
X1age & 33,5457 & 12,5648 & 755 \\
X2size & 19,0411 & 1,6163 & 755 \\
X31 odummy & 0,6795 & 0,4670 & 755 \\
X32idummy & 0,1815 & 0,3857 & 755 \\
X33fdummy & 0,4742 & 0,4997 & 755 \\
\hline
\end{tabular}

In the third regression model, $\mathrm{R}^{2}$ is calculated as 0,147 which indicates that $14,7 \%$ of the variation in financial distress score can be explained by the linear relationship between the company size, company age, CFO, CFI, CFF (cash flow components are calculated as dummy variables) and financial distress score (See Table 13 in the Appendix). $\mathrm{H}_{03}$ is rejected, showing that company size, cash flow from operations and cash flow from finance are significantly related to financial distress score. CFO and company size have negative coefficients which indicate that, one unit increase in the operational cash flow amount would likely to decrease financial distress score nearly 0,11 units and similarly one unit increase in the company size would likely to decrease financial distress score about 0,16 units (See Table 14 and Table 15 in the Appendix). On the contrary, since the standardized coefficient of CFF is negative, one unit increase in CFF causes 0,24 units increase in the financial distress score, meaning to a deterioration in the financial health of companies. The outcomes also indicate that, when a company's net cash flow resulting directly from its regular operations as well as total assets of that company increase, bankruptcy risk decreases while improving financial strength of the related organization. Considering the third model, the results further indicate that cash flows from investment (CFI) and company age do not have any statistically significant relation with financial distress score of companies.

Descriptive statistics of Model 4 is illustrated in Table 5.

Table 5. Descriptive Statistics of Model 4

\begin{tabular}{cccc}
\hline & Mean & Std.Deviation & $\mathrm{N}$ \\
\hline YFD & $-2,4484$ & 1,7561 & 620 \\
X1age & 34,0484 & 13,2704 & 620 \\
X31o & 0,0550 & 0,1354 & 620 \\
X32i & $-0,0481$ & 0,0990 & 620 \\
X33f & 0,0043 & 0,1350 & 620 \\
\hline
\end{tabular}

$\mathrm{R}^{2}$ for the fourth model is calculated as 0,152 , indicating $15,2 \%$ of the variation in financial distress score can be explained by the linear relationship between company age, CFO, CFI, CFF (cash flow components are normalized and divided by total assets) and financial distress score (See Table 16 in the Appendix). $\mathrm{H}_{04}$ is rejected and consequently it is concluded that company age, CFO are statistically significant and have a negative relation with financial distress score of companies. In other words, one unit increase in the company age and CFO would result in 0,12 and 0,17 units of increase in the financial distress score respectively. In addition, according to coefficient estimates, CFF is also statistically significant and has a positive relation with financial distress score such that, one unit increase in the CFF would lead to a 0,23 units of increase in the financial distress score of a company (See Table 17 and Table 18 in the Appendix). The results can be interpreted such that, incase the companies are likely to increase external activities, such as adding loans or issuing and selling more stock, companies' bankruptcy risk increase.

\section{Conclusion}

In this paper, it is investigated whether cash flow components have any effect on predicting financial distress score of companies. In this respect, the study includes 124 companies from manufacturing and service sectors that are quoted in the Istanbul Stock Exchange for the period 2005-2009. Four different models are derived and linear regression analyses are conducted for each equation in which financial distress score is determined as a function of company age, company size, CFO, CFI and CFF. For the first model, it is observed that, cash flow patterns and company size have significant effect on financial distress score of companies. Meanwhile, for the second model no 
significant relation observed between the lagged cash flow components and the financial distress score of firms. In the third model, when the dummy variables of cash flow components are included in the model, it is observed that company size, $\mathrm{CFO}$ and CFF are statistically significant and explain $14,7 \%$ of the variation in financial distress score. Finally fourth equation, in which cash flow components are normalized by dividing the data to total assets, shows that company age, $\mathrm{CFO}$ and $\mathrm{CFF}$ is significantly related to financial distress score of companies. It can be further concluded that CFI does not have any significance in explaining the variation in the financial distress score in any of the models.

The limitation of the study could have arisen from the fact that there are only 620 observations in each variable since the time period of the data covers only 5 years. If time period could be extended, the $\mathrm{R}^{2}$ of the models would likely increase.

For future research it is suggested to extend the study by examining the data according to life cycle stages of companies such that the financial distress score can be defined as a function of cash flow patterns and life cycle stage. Inclusion of life cycle stages would provide information about cash flow pattern differences between early stage, growing and mature companies and further explore whether these differences have any effect on bankruptcy risk in the related firms.

\section{Appendix}

Table 6. Summary Statistics of Model 1

\begin{tabular}{|c|c|c|c|c|c|c|c|c|c|c|}
\hline \multirow[b]{2}{*}{ Model } & \multirow[b]{2}{*}{$\mathrm{R}$} & \multirow{2}{*}{$\begin{array}{c}\mathrm{R} \\
\text { Square }\end{array}$} & \multirow{2}{*}{$\begin{array}{l}\text { Adjusted R } \\
\text { Square }\end{array}$} & \multirow{2}{*}{$\begin{array}{l}\text { Std. Error of the } \\
\text { Estimate }\end{array}$} & \multicolumn{5}{|c|}{ Change Statistics } & \multirow[b]{2}{*}{ Durbin-Watson } \\
\hline & & & & & $\begin{array}{l}\text { R Square } \\
\text { Change }\end{array}$ & $\begin{array}{c}\mathrm{F} \\
\text { Change } \\
\end{array}$ & df1 & df2 & $\begin{array}{c}\text { Sig. F } \\
\text { Change }\end{array}$ & \\
\hline $1^{\mathrm{b}}$ & $0,195^{\mathrm{a}}$ & 0,038 & 0,034 & 2,8117 & 0,038 & 9,909 & 3 & 751 & 0,000 & 1,597 \\
\hline
\end{tabular}

a. Predictors: (Constant), X3pattern, X1age, X2size

b. Dependent Variable: YFD

Table 7. ANOVA of Model 1

\begin{tabular}{ccccccc}
\hline & Model & Sum of Squares & df & Mean Square & F & Sig. \\
\hline $1^{\text {b }}$ & Regression & 235,010 & 3 & 78,337 & 9,909 & $0,000^{\mathrm{a}}$ \\
& Residual & 5937,176 & 751 & 7,906 & & \\
Total & 6172,186 & 754 & & & \\
\hline
\end{tabular}

a. Predictors: (Constant), X3pattern, X1age, X2size

b. Dependent Variable: YFD

Table 8. Coefficients of Model 1

\begin{tabular}{|c|c|c|c|c|c|c|c|c|c|c|}
\hline & \multirow{2}{*}{ Model } & \multicolumn{2}{|c|}{ Unstandardized Coefficients } & \multirow{2}{*}{$\frac{\text { Standardized Coefficients }}{\text { Beta }}$} & \multirow[t]{2}{*}{$\mathrm{t}$} & \multirow[t]{2}{*}{ Sig. } & \multicolumn{2}{|c|}{ Correlations } & \multicolumn{2}{|c|}{ Collinearity Statistics } \\
\hline & & $\mathrm{B}$ & Std. Error & & & & Zero-Order & Partial & Tolerance & VIF \\
\hline \multirow[t]{4}{*}{$1^{\mathrm{a}}$} & Constant & 1,914 & 1,355 & & 1,413 & 0,158 & & & & \\
\hline & Xlage & $-0,007$ & 0,008 & $-0,033$ & $-0,882$ & 0,378 & $-0,073$ & $-0,032$ & 0,942 & 1,061 \\
\hline & $\mathrm{X} 2$ size & $-0,276$ & 0,067 & $-0,139$ & $-3,663$ & 0 & $-0,17$ & $-0,132$ & 0,888 & 1,126 \\
\hline & X3pattern & 0,178 & 0,071 & 0,093 & 2,502 & 0,013 & 0,13 & 0,091 & 0,937 & 1,068 \\
\hline
\end{tabular}

Dependent Variable: YFD

Table 9. Coefficients of Model $2(\mathrm{t}=2006)$

\begin{tabular}{ccccccccccc}
\hline \multirow{2}{*}{ Model } & \multicolumn{2}{c}{ Unstandardized Coefficients } & Standardized Coefficients & $\mathrm{t}$ & $\mathrm{Sig}$. & \multicolumn{2}{c}{ Correlations } & \multicolumn{2}{c}{ Collinearity Statistics } \\
\cline { 2 - 11 } & $\mathrm{B}$ & Std. Error & Beta & & & Zero-order & Partial & Tolerance & VIF \\
\hline $2^{\text {a }}$ & Constant & 1,408 & 1,973 & & 0,714 & 0,477 & & & \\
\\
X106 & $-0,013$ & 0,012 & $-0,099$ & $-1,108$ & 0,27 & $-0,171$ & $-0,101$ & 0,933 & 1,072 \\
X206 & $-0,226$ & 0,095 & $-0,215$ & $-2,368$ & 0,020 & $-0,269$ & $-0,211$ & 0,907 & 1,103 \\
X305 & 0,205 & 0,133 & 0,137 & 1,540 & 0,126 & 0,198 & 0,139 & 0,944 & 1,060 \\
\hline
\end{tabular}

Dependent Variable: Y06 
Table 10. Coefficients of Model 2 ( $\mathrm{t}=2007)$

\begin{tabular}{ccccccccccc}
\hline & \multirow{2}{*}{ Model } & \multicolumn{2}{c}{ Unstandardized Coefficients } & Standardized Coefficients & $\mathrm{t}$ & Sig. & \multicolumn{2}{c}{ Correlations } & \multicolumn{2}{c}{ Collinearity Statistics } \\
\cline { 2 - 11 } & B & Std. Error & Beta & & & Zero-order & Partial & Tolerance & VIF \\
\hline $2^{\text {a }}$ & Constant & 2,123 & 1,864 & & 1,139 & 0,257 & & & & \\
& X107 & $-0,017$ & 0,011 & $-0,135$ & $-1,524$ & 0,130 & $-0,188$ & $-0,138$ & 0,955 & 1,047 \\
& X207 & $-0,248$ & 0,093 & $-0,236$ & $-2,658$ & 0,009 & $-0,277$ & $-0,236$ & 0,945 & 1,058 \\
& X306 & 0,153 & 0,115 & 0,115 & 1,331 & 0,186 & 0,146 & 0,121 & 0,988 & 1,012 \\
\hline
\end{tabular}

Dependent Variable: Y07

Table 11. Coefficients of Model $2(\mathrm{t}=2008)$

\begin{tabular}{ccccccccccc}
\hline \multirow{2}{*}{ Model } & \multicolumn{2}{c}{ Unstandardized Coefficients } & \multicolumn{2}{c}{ Standardized Coefficients } & t & Sig. & \multicolumn{2}{c}{ Correlations } & \multicolumn{2}{c}{ Collinearity Statistics } \\
\cline { 2 - 10 } & B & Std. Error & Beta & & & Zero-order & Partial & Tolerance & VIF \\
\hline $2^{\text {a }}$ & Constant & 1,695 & 2,347 & & 0,722 & 0,472 & & & & \\
& X108 & $-0,018$ & 0,014 & $-0,113$ & $-1,251$ & 0,213 & $-0,145$ & $-0,109$ & 0,944 & 1,060 \\
X208 & $-0,206$ & 0,117 & $-0,161$ & $-1,768$ & 0,080 & $-0,216$ & $-0,155$ & 0,916 & 1,091 \\
X307 & 0,242 & 0,129 & 0,166 & 1,866 & 0,064 & 0,191 & 0,163 & 0,965 & 1,036 \\
\hline
\end{tabular}

Dependent Variable: Y08

Table 12. Coefficients of Model $2(t=2009)$

\begin{tabular}{ccccccccccc}
\hline \multirow{2}{*}{ Model } & \multicolumn{2}{c}{ Unstandardized Coefficients } & \multicolumn{2}{c}{ Standardized Coefficients } & $\mathrm{t}$ & $\mathrm{S}$ Sig. & \multicolumn{2}{c}{ Correlations } & \multicolumn{2}{c}{ Collinearity Statistics } \\
\cline { 2 - 10 } & B & Std. Error & Beta & & & Zero-order & Partial & Tolerance & VIF \\
\hline $2^{\text {a }}$ & Constant & 0,425 & 2,028 & & 0,210 & 0,834 & & & & \\
& X109 & $-0,014$ & 0,012 & $-0,112$ & $-1,224$ & 0,223 & $-0,176$ & $-0,111$ & 0,919 & 1,088 \\
X209 & $-0,150$ & 0,096 & $-0,148$ & $-1,568$ & 0,120 & $-0,216$ & $-0,142$ & 0,868 & 1,152 \\
& X308 & 0,163 & 0,117 & 0,130 & 1,398 & 0,165 & 0,198 & 0,127 & 0,888 & 1,126 \\
\hline
\end{tabular}

Dependent Variable: Y09

Table 13. Summary Statistics of Model 3

\begin{tabular}{|c|c|c|c|c|c|c|c|c|c|c|}
\hline \multirow[b]{2}{*}{ Model } & \multirow[b]{2}{*}{$\mathrm{R}$} & \multirow{2}{*}{$\begin{array}{c}\mathrm{R} \\
\text { Square }\end{array}$} & \multirow{2}{*}{$\begin{array}{l}\text { Adjusted R } \\
\text { Square }\end{array}$} & \multirow{2}{*}{$\begin{array}{l}\text { Std. Error of the } \\
\text { Estimate }\end{array}$} & \multicolumn{5}{|c|}{ Change Statistics } & \multirow[b]{2}{*}{ Durbin-Watson } \\
\hline & & & & & $\begin{array}{l}\text { R Square } \\
\text { Change }\end{array}$ & $\begin{array}{c}\mathrm{F} \\
\text { Change }\end{array}$ & df1 & $\mathrm{df} 2$ & $\begin{array}{c}\text { Sig. F } \\
\text { Change }\end{array}$ & \\
\hline $3^{\mathrm{b}}$ & $0,291^{\mathrm{a}}$ & 0,085 & 0,079 & 2,7464 & 0,085 & 13,863 & 5 & 749 & 0,000 & 1,586 \\
\hline
\end{tabular}

a. Predictors: Constant, X1age, X2size, X31 odummy, X32idummy, X33fdummy

b. Dependent Variable: YFD

Table 14. ANOVA of Model 3

\begin{tabular}{ccccccc}
\hline & Model & Sum of Squares & df & Mean Square & F & Sig. \\
\hline $3^{\mathrm{b}}$ & Regression & 522,797 & 5 & 104,559 & 13,863 & $0,000^{\mathrm{a}}$ \\
& Residual & 5649,389 & 749 & 7,543 & & \\
& Total & 6172,186 & 754 & & & \\
\hline
\end{tabular}

a. Predictors: Constant, X33fdummy, X2size, X32idummy, X1age, X31 odummy

b. Dependent Variable: YFD

Table 15. Coefficients of Model 3

\begin{tabular}{|c|c|c|c|c|c|c|c|c|c|c|}
\hline & \multirow{2}{*}{ Model } & \multicolumn{2}{|c|}{$\begin{array}{l}\text { Unstandardized } \\
\text { Coefficients }\end{array}$} & \multirow{2}{*}{$\begin{array}{c}\text { Standardized } \\
\text { Coefficients } \\
\text { Beta }\end{array}$} & \multirow[t]{2}{*}{$\mathrm{t}$} & \multirow[t]{2}{*}{ Sig. } & \multicolumn{2}{|c|}{ Confidence Interval } & \multicolumn{2}{|c|}{$\begin{array}{l}\text { Collinearity } \\
\text { Statistics }\end{array}$} \\
\hline & & B & Std. Error & & & & $\begin{array}{l}\text { Lower } \\
\text { Bound }\end{array}$ & $\begin{array}{l}\text { Upper } \\
\text { Bound }\end{array}$ & Tolerance & VIF \\
\hline \multirow[t]{6}{*}{$3^{\mathrm{a}}$} & Constant & 2,706 & 1,223 & & 2,214 & 0,027 & 0,306 & 5,106 & & \\
\hline & $\mathrm{X}$ lage & $-0,005$ & 0,008 & $-0,024$ & $-0,661$ & 0,509 & $-0,022$ & 0,011 & 0,937 & 1,067 \\
\hline & $\mathrm{X} 2$ size & $-0,249$ & 0,067 & $-0,141$ & $-3,731$ & 0,000 & $-0,381$ & $-0,118$ & 0,856 & 1,168 \\
\hline & X31odummy & $-0,658$ & 0,244 & $-0,107$ & $-2,699$ & 0,007 & $-1,137$ & $-0,179$ & 0,772 & 1,296 \\
\hline & X32idummy & $-0,311$ & 0,270 & $-0,042$ & $-1,152$ & 0,249 & $-0,841$ & 0,219 & 0,924 & 1,083 \\
\hline & X33fdummy & 0,937 & 0,223 & 0,164 & 4,196 & 0,000 & 0,498 & 1,375 & 0,804 & 1,244 \\
\hline
\end{tabular}

Dependent Variable: YFD 
Table 16. Summary Statistics of Model 4

\begin{tabular}{|c|c|c|c|c|c|c|c|c|c|c|}
\hline \multirow[b]{2}{*}{ Model } & \multirow[b]{2}{*}{$\mathrm{R}$} & \multirow[b]{2}{*}{$\begin{array}{c}\mathrm{R} \\
\text { Square }\end{array}$} & \multirow[b]{2}{*}{$\begin{array}{l}\text { Adjusted R } \\
\text { Square }\end{array}$} & \multirow[b]{2}{*}{$\begin{array}{l}\text { Std. Error of the } \\
\text { Estimate }\end{array}$} & \multicolumn{5}{|c|}{ Change Statistics } & \multirow[b]{2}{*}{ Durbin-Watson } \\
\hline & & & & & $\begin{array}{l}\text { R Square } \\
\text { Change }\end{array}$ & $\begin{array}{c}\mathrm{F} \\
\text { Change }\end{array}$ & df1 & $\mathrm{df} 2$ & $\begin{array}{c}\text { Sig, F } \\
\text { Change }\end{array}$ & \\
\hline $4^{b}$ & $0,389^{a}$ & 0,152 & 0,146 & 1,623 & 0,152 & 27,471 & 4 & 615 & 0,000 & 1,718 \\
\hline
\end{tabular}

a. Predictors: Constant, X1age, X31o, X32i, X33f

b. Dependent Variable: YFD

Table 17. ANOVA of Model 4

\begin{tabular}{ccccccc}
\hline & Model & Sum of Squares & df & Mean Square & F & Sig. \\
\hline $4^{\mathrm{b}}$ & Regression & 289,345 & 4 & 72,336 & 27,471 & $0,000^{\mathrm{a}}$ \\
& Residual & 1619,433 & 615 & 2,633 & & \\
& Total & 1908,777 & 619 & & & \\
\hline
\end{tabular}

a. Predictors: Constant, X1age, X31o, X32i, X33f

b. Dependent Variable: YFD

Table 18. Coefficients of Model 4

\begin{tabular}{|c|c|c|c|c|c|c|c|c|c|c|}
\hline \multirow[b]{2}{*}{ Model } & & \multicolumn{2}{|c|}{$\begin{array}{c}\text { Unstandardized } \\
\text { Coefficients }\end{array}$} & \multirow{2}{*}{$\begin{array}{c}\begin{array}{c}\text { Standardized } \\
\text { Coefficients }\end{array} \\
\text { Beta } \\
\end{array}$} & \multirow{2}{*}{$\mathrm{t}$} & \multirow{2}{*}{ Sig. } & \multicolumn{2}{|c|}{ Correlations } & \multicolumn{2}{|c|}{$\begin{array}{c}\text { Collinearity } \\
\text { Statistics }\end{array}$} \\
\hline & & B & Std. Error & & & & Zero-order & Partial & $\begin{array}{l}\text { Toler } \\
\text { ance }\end{array}$ & VIF \\
\hline \multirow[t]{5}{*}{$4^{\mathrm{a}}$} & (Constant) & $-1,707$ & 0,189 & & $-9,050$ & 0,000 & & & & \\
\hline & Xlage &,- 016 & 0,005 & $-0,123$ & $-3,278$ & 0,001 & $-0,138$ & $-0,131$ & 0,978 & 1,023 \\
\hline & $\mathrm{X} 310$ & $-2,135$ & 0,739 & $-0,165$ & $-2,889$ & 0,004 & $-0,335$ & $-0,116$ & 0,425 & 2,354 \\
\hline & $\mathrm{X} 32 \mathrm{i}$ & 1,716 & 0,837 & 0,097 & 2,050 & 0,041 & 0,055 & 0,082 & 0,620 & 1,613 \\
\hline & X33f & 3,027 & 0,749 & 0,233 & 4,042 & 0,000 & 0,319 & 0,161 & 0,416 & 2,404 \\
\hline
\end{tabular}

Dependent Variable: YFD

\section{REFERENCES}

[1] J. A. Gentry, P. Newbold, and D.T. Whitford. Profiles of cash flow components. Financial Analysts Journal. 41-48, 1990.

[2] V. Dickinson. Cash flow patterns as a proxy for firm life cycle. Fisher School of Accounting - Warrington College of Business Unversity of Florid, 2007

[3] M. Gort and S. Klepper. Time paths in the diffusion of product innovation. Economic Journal. Vol. 92, 630-653, 1982.

[4] R. M. Bowen, D. Burgstahler, and L. A., Daley, The incremental information content of accrual versus cash flows, Accounting Review, 723-747, 1987.

[5] V. L. Bernard and T. L. Stober. The Nature and Amount of Information in Cash Flows and Accruals. The Accounting Review Vol. 14, 624-652, 1989.

[6] G. Wilson. The Relative Incremental Information Content of
Accruals and Cash Flows: Combined Evidence at the Earnings Announcement and Annual Report Date. Journal of Accounting Research. 165-200, 1986.

[7] E. L.Black. Life-cycle impacts on the incremental value-relevance of earnings and cash flow measures. Journal of Financial Statement Analysis Vol. 4, 40-57, 1998.

[8] S. Myers. The capital structure puzzle Journal of Finance Vol. 39, 575-592, 1984.

[9] G. Joseph and R. Lipka. "Distressed firms and the secular deterioration in usefulness of accounting information. Journal of Business Research. Vol. 59, 295-303, 2006.

[10] J. Livnat and P. Zarowin. The incremental information content of cash flow components, Journal of Accounting and Economics Vol. 13, 25-46, 1990.

[11] P. Dechow. Accounting earnings and cash flows as measures of firm performance: The role of accounting accruals. Journal of Accounting and Economics, Vol. 18, 3-42, 1994.

[12] M. E. Zmijewski. Methodological issues related to the estimation of financial distress prediction models. Journal of Accounting Research Vol. 22, 59-82, 1984. 